\section{Plasma Glutamine in a Phenylketonuric Family with Normal and Mentally Defective Members}

The pathogenesis underlying the brain defect in phenylketonuria is still unknown. Perry et al. (1970) reported a biochemical comparison of two brothers with untreated phenylketonuria (PKU) of whom one had severe mental retardation. The other was of superior intelligence. The only difference found between the plasma amino acid pattern of the two brothers was a significantly diminished concentration of glutamine in the mentally retarded subject, also seen in 12 other untreated subjects with PKU, whereas in the intelligent brother the concentration was in the normal range. A further described untreated subject with PKU and normal intelligence showed a glutamine concentration in the normal range. Among several hypotheses, Perry et al. (1970) suggested that a chronic deficiency of glutamine might play a part in causing the mental defect in untreated phenylketonuria.

We have encountered a family with three severely affected mentally retarded children with PKU (Table). Their mother, as well as her brother, also suffered from PKU, but presented a normal and borderline intelligence (IQ 90 and 80 respectively). The father of the children was shown by phenylalanine loading tests to be a heterozygote. Clinical and biochemical details were published earlier (Colombo et al., 1967). In the meantime the eldest boy (born 1955) died at the age of 14 from recurrent pneumonia.

In view of this particular constellation with severe mentally affected and normal members in the same family, glutamine determinations were done in plasma.

\section{Methods}

Plasma amino acids were determined using a Technicon amino acid-Analyzer according to the method of Efron (1966). Only phenylalanine and glutamine values are reported. Special precautions necessary for accurate measurement of plasma glutamine were observed as indicated by Perry and Hansen (1969). Heparin was used as anticoagulant. The analysis of a heparinized tube filled with water gave no glutamine. A fasting blood specimen was drawn in the morning, immediately deproteinized with solid sulphosalicylic acid (Efron, 1966), centrifuged, and the supernatant analysed the same day. The same procedure was done to establish the normal values. Using these precautions, a minimal disintegration of glutamine can be expected. $\mathrm{o}-\mathrm{OH}-$ phenylacetic acid and phenylpyruvic acid were determined according to the method of Humbel $(1963,1964)$.

\section{Results}

The concentration of glutamine in the affected two children was within the 2 SD limit of the normal

TABLE

Biochemical and Clinical Findings in the PKU Family Members

\begin{tabular}{|c|c|c|c|c|c|}
\hline & $\begin{array}{l}\text { First } \\
\text { Child }\end{array}$ & $\begin{array}{l}\text { Second } \\
\text { Child }\end{array}$ & Mother & $\begin{array}{l}\text { Brother } \\
\text { of Mother }\end{array}$ & $\begin{array}{c}\text { Normal } \\
\text { Subjects }(n=10)\end{array}$ \\
\hline $\begin{array}{l}\text { Sex } \\
\text { Year of birth } \\
\text { IQ } \\
\text { Electroencephalogram } \\
\text { Plasma ( } \mu \text { moles } / 100 \mathrm{ml} \text { ) } \\
\text { Phenylalanine } \\
\text { Glutamine }\end{array}$ & $\begin{array}{c}F \\
1953 \\
<10 \\
\text { Pathological } \\
\\
88-167 \\
41 \cdot 6\end{array}$ & $\begin{array}{c}\mathrm{F} \\
1957 \\
<10 \\
\text { Pathological } \\
\\
99-194 \\
34 \cdot 6\end{array}$ & $\begin{array}{c}F \\
1932 \\
90 \\
\text { Normal } \\
\\
150-260 \\
26 \cdot 9\end{array}$ & $\begin{array}{c}M \\
1934 \\
80 \\
\text { Normal } \\
86-159 \\
30 \cdot 5\end{array}$ & $\begin{aligned} 5 \cdot 9 & \pm 0.94^{\star} \\
36 \cdot 2 & \pm 0.61\end{aligned}$ \\
\hline $\begin{array}{l}\text { Urine }(\mu \mathrm{g} / \mathrm{mg} \text { creatinine }) \\
\text { Phenylalanine } \\
\text { Phenylpyruvic acid } \\
\text { o-OH-Phenylacetic acid }\end{array}$ & $\begin{array}{l}119 \\
302 \\
111\end{array}$ & $\begin{array}{l}153 \\
408 \\
168\end{array}$ & $\begin{array}{l}161 \\
257 \\
159\end{array}$ & $\begin{array}{l}200 \\
373 \\
144\end{array}$ & $\frac{15-45 t}{0 \cdot 15-1 \cdot 4}$ \\
\hline
\end{tabular}

Mean \pm 2 SD. 
values (Table). The lowest concentration was found in the mother who has the highest IQ of all family members. The highest concentration was obtained in the first child who was severely mentally defective. Apart from low values of threonine and tyrosine in all family members, no uniform trend in the distribution of the other amino acids in the plasma of the mentally affected children and the two adults with normal and borderline intelligence could be detected.

\section{Discussion}

Perry et al. (1970) found a low concentration of glutamine to be the only significant disturbance in plasma amino acid pattern in untreated $P K U$ patients with defective mental development. Two phenylketonuric adults with normal and borderline intelligence did not have a low plasma concentration of glutamine.

In the family we have studied, the glutamine levels were in the normal range in all members except in the mother who presented the highest IQ. These observations indicate that in these cases a pathogenic effect of glutamine depletion on the brain function is difficult to accept. More cases with a similar familial structure must be studied to give a definite answer as to the damaging effect of glutamine depletion in PKU.*

\section{Summary}

Plasma glutamine analyses were done in two severely retarded phenylketonuric sibs and in their mother and her brother, both of near normal intelligence.

The concentration of glutamine lay in the normal range, except in the subject with the highest $I Q$. These observations cast some doubt as to the damaging effect of CNS glutamine depletion in PKU.

\section{REFERENCES}

Colombo, J. P., Vassella, F., Humbel, R., and Rossi, E. (1967). Phenylketonuria: a family study. Helvetica Paediatrica Acta 22. 243.

Efron, M. L. (1966). Quantitative estimation of amino acids in physiological fluids using a Technicon Amino Acid Analyzer. Technicon Symposium: Automation in Analytical Chemistry, 1965 , p. $637 . \quad$ Median, New York.

Humbel, R. (1963). Identification et dosage de l'acide phénylpyruvique dans l'urine. Laboratoire Médicale, 16, 123.

Humbel, R. (1964). Dosage de l'acide ortho-hydroxyphénylacetique dans l'urine. Laboratoire Médicale, 18, 241.

McKean, C. M., and Peterson, N. A. (1970). Glutamine in the phenylketonuric central nervous system. New England fournal of Medicine, 283, 1364.

«Since this paper was submitted, McKean and Peterson (1970) reported increased concentrations of glutamine in CSF and brain tissue of untreated retarded PKU subjects. Their findings also do not support the hyposesis that glutamine depletion in CNS is responsible for cerebral abnormalities in PKU.
Perry, T. L., and Hansen, S. (1969). Technical pitfalls leading to errors in the quantitation of plasma amino acids. Clinica Chimica Acta, 25, 53.

Perry, T. L., Hansen, S., Tischler, B., Bunting, R., and Diamond, S. (1970). Glutamine depletion in phenylketonuria. New England fournal of Medicine, 282, 761.

\section{J. P. Соцомво}

The Chemical Central Laboratory, Inselspital and Department of Pediatrics, University of Berne, Switzerland.

\section{Cephalhaematomata with Disseminated Intravascular Coagulation}

Disseminated intravascular coagulation may be associated with many illnesses in the newborn period, such as viral infections (Hathaway, Mull, and Pechet, 1969) and the respiratory distress syndrome (Du, Briggs, and Young, 1970; Stark, Abramson, and Erkan, 1968)

It also occurs with pregnancy complications in the mother, such as pre-eclamptic toxaemia (PET) (Leissring and Vorlicky, 1968) and antepartum haemorrhage (APH) (Edson et al., 1968). Few cases have survived. The case described by Berglund (1970) was treated successfully however with heparin. We have encountered two cases of disseminated intravascular coagulation in the newborn who survived without specific treatment. They were unusual in that they presented with bilateral subperiosteal cephalhaematomata within 24 hours of birth.

\section{Case Reports}

Case 1. A girl, birthweight $2 \cdot 8 \mathrm{~kg}$, was born at term after a surgical induction of labour. The mother was a 22-year-old gravida I whose pregnancy had been uneventful. The delivery was spontaneous by the vaginal route. At 1 minute the baby had an Apgar score of 1 and at 5 minutes an Apgar score of 5 . Resuscitation was performed by suction, and oxygen was given via the Cardiff bag. She was admitted to the Special Care Unit at 30 minutes of age with a rectal temperature of $36^{\circ} \mathrm{C}$. She was given $2 \mathrm{mg}$ vitamin $\mathrm{K}$ on admission. She was wasted but was otherwise healthy, was not juddery, and the anterior fontanelle tension was considered normal. At 15 hours of age when bilateral subperiosteal cephalhaematomata were noted, coagulations studies were performed (Table I). The question of heparin therapy was discussed, but decided against in view of the fact that the child was clinically very well. She was eventually discharged at 2 weeks of age. At follow-up, development seems completely normal. 